Research Article

Weiwei Liu ${ }^{1}$, Kun Zhang ${ }^{1 \star}$, Zhenxue Jiang*, Shu Jiang*, Yan Song, Chengzao Jia, Yizhou Huang, Ming Wen, Tianlin Liu, Xuelian Xie, Pengfei Wang, Chang'an Shan, Xiaoxue Liu, and Xin Wang

\title{
Effect of the hydrothermal activity in the Lower Yangtze region on marine shale gas enrichment: A case study of Lower Cambrian and Upper Ordovician-Lower Silurian shales in Jiangye-1 well
}

https://doi.org/10.1515/geo-2018-0046

Received June 27, 2018; accepted September 4, 2018

Abstract: Finding favorable sites for the exploration of shale gas, is still one of the important areas of research that needs immediate attention. The content of organic matter in shale plays a crucial role in the hydrocarbon generation potential, reservoir space and gas-bearing capacity of shales. Therefore, studying the sedimentary environment of organic shale can provide a scientific basis for locating favorable exploration areas for shale gas. The article takes the Lower Cambrian and the Upper OrdovicianLower Silurian shales in the Yangtze region as the research object and selects representative wells to quantitatively calculate the existence of excess silicon in shale siliceous minerals and the content of excess silicon. Then, the origin of excess silicon can be clarified by the $\mathrm{Al}, \mathrm{Fe}$ and Mn elemental analysis. Finally, the sedimentary organic matter enrichment mechanism is analyzed from water oxidation-reduction environments and biological productivity. The results of the study show that the excess silicon in the Lower Cambrian and Upper Ordovician-Lower Silurian shales in the Lower Yangtze region is of hydrothermal origin. The hydrothermal activity improves biological fertility on the one hand; whereas on the other hand, it can enhance the reducing capacity of the bottom water conducive for the preservation of organic matter thereby enriching the sedimentary organic matter. The place near the junction of Yangtze plate and Cathaysian plate, where hydrothermal activities were more intense, provided favorable loci for shale gas exploration in the Lower Yangtze region. It was observed that, since the hydrothermal activity was stronger in the Early Cambrian than in the Late Ordovician-Early Silurian times, the total organic carbon (TOC) content of the Lower Cambrian shale was higher than that of the Upper Ordovician-Lower Silurian shales.

Keywords: Marine shale hydrocarbons; Lower Yangtze basin; Cambrian-Ordovician-Silurian shales; Hydrother- mal silica enrichment; Biological fertility; Redox of water body

`Corresponding Author: Kun Zhang ${ }^{1}$ : State Key Laboratory of Petroleum Resources and Prospecting, China University of Petroleum, Beijing 102249, China; Unconventional Natural Gas Institute, China University of Petroleum, Beijing 102249, China; Unconventional Petroleum Collaborative Innovation Center, China University of Petroleum, Beijing 102249, China; Research Institute of Petroleum Exploration and Development, Beijing 100083, China; Energy and Geoscience Institute, University of Utah, Salt Lake City, Utah 84108, United States; E-mail: shandongzhangkun@126.com ^Corresponding Author: Zhenxue Jiang: State Key Laboratory of Petroleum Resources and Prospecting, China University of Petroleum, Beijing 102249, China; Unconventional Natural Gas Institute, China University of Petroleum, Beijing 102249, China; E-mail: zhenxuejiangedu@126.com

*Corresponding Author: Shu Jiang: Energy and Geoscience Institute, University of Utah, Salt Lake City, Utah 84108, United States; Research Institute of Unconventional Oil \& Gas and Renewable Energy, China University of Petroleum (East China), China; E-mail: sjiang@egi.utah.edu

Weiwei Liu ${ }^{1}$ : Jiangxi Provincial Natural Gas Company, Ltd., Nanchang 330000, China

Yan Song: State Key Laboratory of Petroleum Resources and Prospecting, China University of Petroleum, Beijing 102249,

China; Unconventional Natural Gas Institute, China University of Petroleum, Beijing 102249, China; Research Institute of Petroleum Exploration and Development, Beijing 100083, China

Chengzao Jia: Research Institute of Petroleum Exploration and Development, Beijing 100083, China

Yizhou Huang, Ming Wen, Tianlin Liu, Xiaoxue Liu, Xin Wang: State Key Laboratory of Petroleum Resources and Prospecting, China University of Petroleum, Beijing 102249, China; Unconventional Natural Gas Institute, China University of Petroleum, Beijing 102249, China

Xuelian Xie: Guangzhou Marine Geological survey, Guangzhou 510760, China

Pengfei Wang: Geoscience Documentation Center. China Geological Survey, Beijing 100083, China

Chang'an Shan: School of Earth Sciences and Engineering, Xi'an Shiyou University, Xi'an 710065, China

${ }^{1}$ These authors contributed equally to this work. 


\section{Introduction}

As early as 1821, the first shale gas well was drilled on the United States. In 1914, the first shale gas field, Big Sandy, was discovered in the United States. In 1981, George Michel, known as the father of shale gas, has enabled the commercial development of Barnett shale gas using the large hydraulic fracturing technology, and shale gas has received increasing attention as a natural gas resource $[1$, 2]. Since 2000, with the transformation of exploration approaches and the development of technology, the shale gas industry has achieved great success in North America. The shale gas production in North America was only $117.96 \times 10^{8} \mathrm{~m}^{3}$ in 2000 . In 2005 , the horizontal well fracturing technology became more and more mature, and shale gas production has grown rapidly. With the development of large shale gas fields such as Marcellus, the shale gas production has increased to $4,621 \times 10^{8} \mathrm{~m}^{3}$ in 2017 [1-4]. In addition, Canada, China and Brazil have also realized commercial development of shale gas.

China also has extensive shale gas resources. Since 2010, commercial development has been carried out in the Weiyuan, Changning, Zhaotong, Fushun Yongchuan, Fuling and Dingshan blocks. In the year of 2017, the shale gas production of Weiyuan and Changing was $24.73 \times 10^{8} \mathrm{~m}^{3}$, that of Zhaotong was over $5 \times 10^{8} \mathrm{~m}^{3}$, and that of Fuling was $60.04 \times 10^{8} \mathrm{~m}^{3}$ [5-9]. Organic matter is crucial for hydrocarbon generation in shale, and the content of organic carbon in shale is controlled by the abundance of original organic matter in the shale. The content of organic matter in shale plays a decisive role in shale potential, reservoir space and gas-bearing capacity [10-14]. Therefore, studying the influence of the sedimentary environment on organic matter enrichment and analyzing the temporal and spatial distribution characteristics of organic matter can provide a scientific basis for finding favorable exploration areas for shale gas [15].

A series of methods have been used to study the accumulation mechanism of organic matter in the marine sediments of the Yangtze area. Based on outcrop, drilling core and well logging data, and shale organic geochemistry analysis, and sedimentary facies, $\mathrm{Li}$ et al. analyzed the sedimentary microfacies characteristics and gas-bearing characteristics of the Qiongzhusi shale of the Lower Cambrian in the southern Sichuan basin [16]. Mou et al. used microscopy, X-Ray Diffraction and geochemical data to constrain the impact characteristics of geological conditions for shale gas deposits of the Longmaxi Formation in the Lower Silurian, southern Sichuan and its adjacent areas [17]. Liu et al. suggested a fine division scheme for shale sedimentary facies and established the evolution model of shale deposition through comprehensive research based on data from outcrops, cores, slices, mineral X-ray diffraction, argon ion polishing, scanning electron microscopy and drilling [18]. According to organic carbon content and testing for major and trace elements, Zhang et al. studied the sedimentary environment of organic-rich shale and its influence on organic matter content in the Lower Cambrian strata [19].

The large-scale exploration for shale gas in recent years has provided more new data for the study of the mechanism of sedimentary organic matter enrichment. A shale formation contains a variety of elements, such as silicon, calcium, aluminum, uranium, thorium, potassium, iron, manganese and so on. The origin of siliceous minerals has been elaborately studied by previous workers. Holdaway and Clayton defined the concept of excess silicon, which means excessive silicon beyond the source of normal terrigenous clasts, and proposed a quantitative calculation method for this excess silicon [20]. Subsequently, Wedepohl, Adachi et al. and Yamamoto also proposed a method to determine whether siliceous minerals are hydrothermal or biogenic by using $\mathrm{Al}-\mathrm{Fe}-\mathrm{Mn}$ triangular plots [21-23]. This paper combines two steps of calculation methods; first, it calculates the existence of excess silicon for shale siliceous minerals in a quantitative way and calculates the content of excess silicon. Then it determines the causes of excess silicon, analyzes the enrichment mechanism of sedimentary organic matter, identify the favorable area for shale gas enrichment and compares the difference of sedimentary organic matter enrichment between the Early Cambrian and the Late Ordovician to Early Silurian in the Lower Yangtze region.

\section{Geological settings}

\subsection{Sedimentary and stratum characteristics}

\subsubsection{The Lower Cambrian}

Previous studies [19, 24-26] have shown that, as shown in the Early Cambrian, facies in the Yangtze plate are successively ancient land, shallow shelf and deep-water shelf (intra-shelf low), continental slope and ocean basin from northwest to southeast (Fig. 1A). Corresponding to the Cathaysian plate, the facies are successively ocean basin, continental slope, deep shelf, shallow shelf and ancient land. The Yangtze plate and the Cathaysian plate abut un- 
der the ocean, where the water is the deepest and becomes gradually shallower to both sides of the ancient land.

The Lower Cambrian strata is widely deposited in the Yangtze plate and the Cathaysian plate as a set of strata called by different names in different regions due to its wide range of distribution. In the Lower Yangtze area, it is called the Wangyinpu Formation, composed of organicrich siliceous shale colored black to dark gray and deposited in an Early Cambrian sedimentary basin, which is one of the intervals under development in the Chinese shale gas industry.

\subsubsection{The Upper Ordovician-Lower Silurian}

Previous studies [17, 27, 28] have shown that the Yangtze plate and Cathaysian plate converged and collided in the Late Ordovician-Early Silurian (Fig. 1B). As the Lower Yangtze region is relatively narrow and near the junction of the two plates, a foreland basin was formed by lithospheric flexure.

The Upper Ordovician-Lower Silurian is another prominent target interval in the exploration and development of shale gas in the south of China. The lithologic characteristics of the Xinkailing Formation in the Upper Ordovician and the Lishuwo Formation in the Lower Silurian are dichotomous: the Xinkailing Formation and the lower part of the first section in the Lishuwo Formation are mainly a combination of black siliceous shale and dark gray calcareous shale. The higher part of the first section in the Lishuwo is a combination of shale, sandy shale and siltstone colored gray green and yellow green.

\subsection{Tectonic characteristics}

The original continental crust in southern China was divided into two plates, the Yangtze and the Cathaysian, separated by an oceanic basin in the Early Proterozoic, when the Yangtze plate was a cratonic basin [29-31]. In the Early Cambrian, the two plates were in a state of tension with large-scale transgression. At the same time, there deposited a set of organic-rich shale throughout almost the entire plate. Subsequently, the water gradually became shallow, and the lithology changed from finegrained shale and silty shale to coarse clastic rocks such as siltstone and sandstone. In the Ordovician, the Cathaysian plate was affected by collision, leading the water to become shallow and the lithology to change from a clastic sedimentary system to a carbonate sedimentary system. In the Late Ordovician-Early Silurian, a scare transgres- sion occurred, the lithology changed back to a clastic sedimentary system, and a set of rich shale accumulated in a deep-water shelf area. During the Cambrian to Silurian, the ocean basin between the two plates gradually subducted and collided with the Yangtze plate. In addition, in the Late Silurian, the Yangtze and Cathaysian plates officially combined into one unified southern China plate [2931].

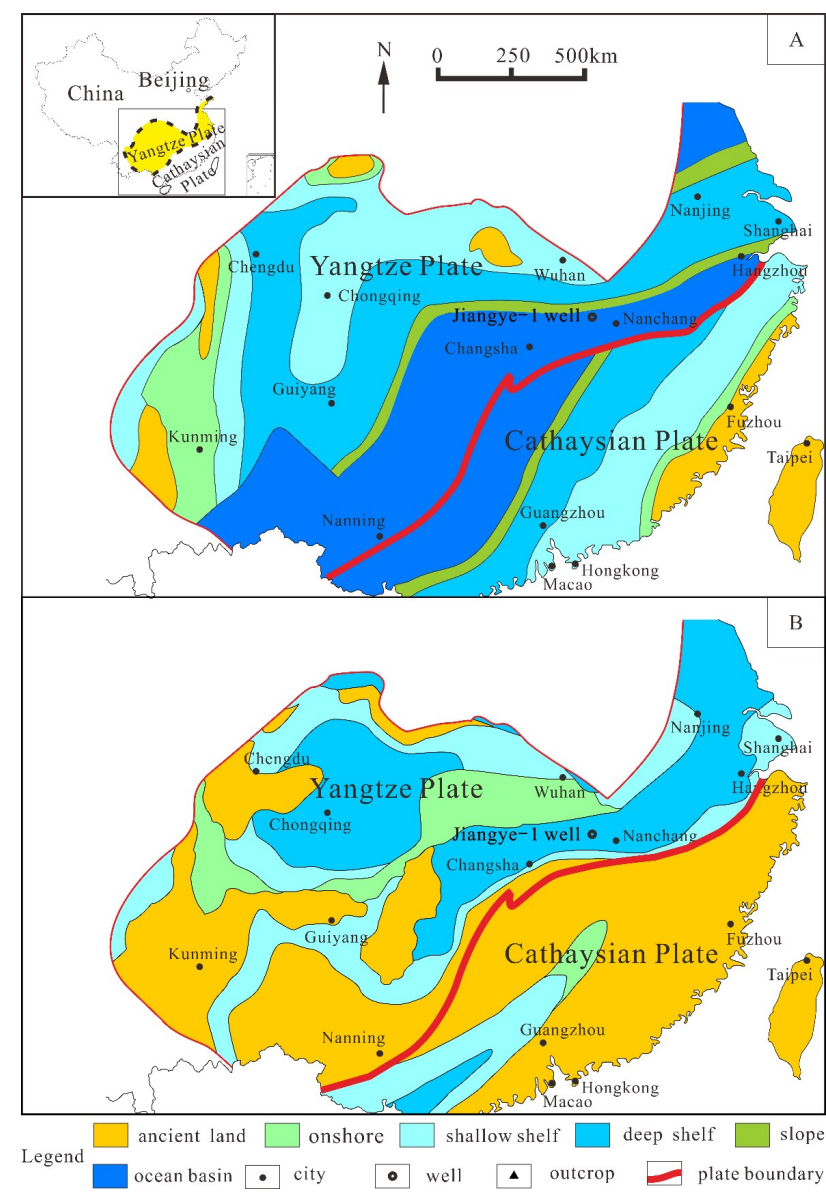

Figure 1: Regional sedimentary characteristics of southern China in the Early Cambrian (A) and in the Late Ordovician-Early Silurian (B). Modified from references [17, 19, 24-28].

\section{Samples, experiments and data sources}

Well Jiangye-1, located in the shale gas blocks of the Xiuwu basin in the Lower Yangtze region of the Yangtze plate, is a key exploration well drilled into the two sets of shale strata of the Lower Cambrian and the Upper Ordovician-Lower 
Silurian. In the Early Cambrian and in the Late OrdovicianEarly Silurian, the Lower Yangtze area accumulated largescale marine deposits with little change in facies. Therefore, this study selected data from Well Jiangye-1 as the example to analyze the enrichment mechanism for sedimentary organic matter in the Early Cambrian and the Late Ordovician-Early Silurian in the Lower Yangtze region.

Twenty-eight pieces of core samples were taken from Well Jiangye-1 in the Wangyinpu Formation in the Lower Cambrian and forty-two cores in the Upper Ordovician Xinkailing-Lower Silurian first section of the Lishuwo Formation. The TOC content of these samples was tested by the total organic carbon analyzer OG-2000V. The Poro PDP200 porosity tester was used to measure the effective porosity of the samples. The core samples from $2617 \mathrm{~m}$ of Wangyinpu Formation in the Jiangye-1 well was observed by focused ion beam scanning electron microscopy (FIB-SEM).

Eighty-four pieces of core samples were taken from Well Jiangye-1 in the Wangyinpu Formation in the Lower Cambrian and ninety-one pieces in the first section of the Lishuwo Formation in the Upper Ordovician-Lower Silurian. Elements such as $\mathrm{Ba}, \mathrm{Al}, \mathrm{Fe}$ and $\mathrm{Mn}$ in these samples were analyzed by X-ray fluorescence spectrometry (Xray Fluorescence) with the model Axios-MAX. The Si, Al, $\mathrm{U}$ and Th logging data of Well Jiangye-1 provided by the Schlumberger Corp were also combined in this paper.

\section{Results and Discussion}

\subsection{The effect of organic matter on the development of shale reservoir}

\subsubsection{The relationship between the content of TOC and the effective porosity}

According to the correlogram between the TOC content and effective porosity of core samples from Upper Ordovician Xinkailing-Lower Silurian first section of the Lishuwo Formation and Lower Cambrian Wangyinpu formation in Jiangye 1well (see Fig. 2A, 2B), it can be seen that there is a good correlation between the two, indicating that the effective pores are mainly developed in organic matter.

\subsubsection{Analysis of the connectivity of organic pores by FIB-SEM Technology}

The extraction of organic matter of shale and the identification of connectivity pores can be realized by FIB-SEM
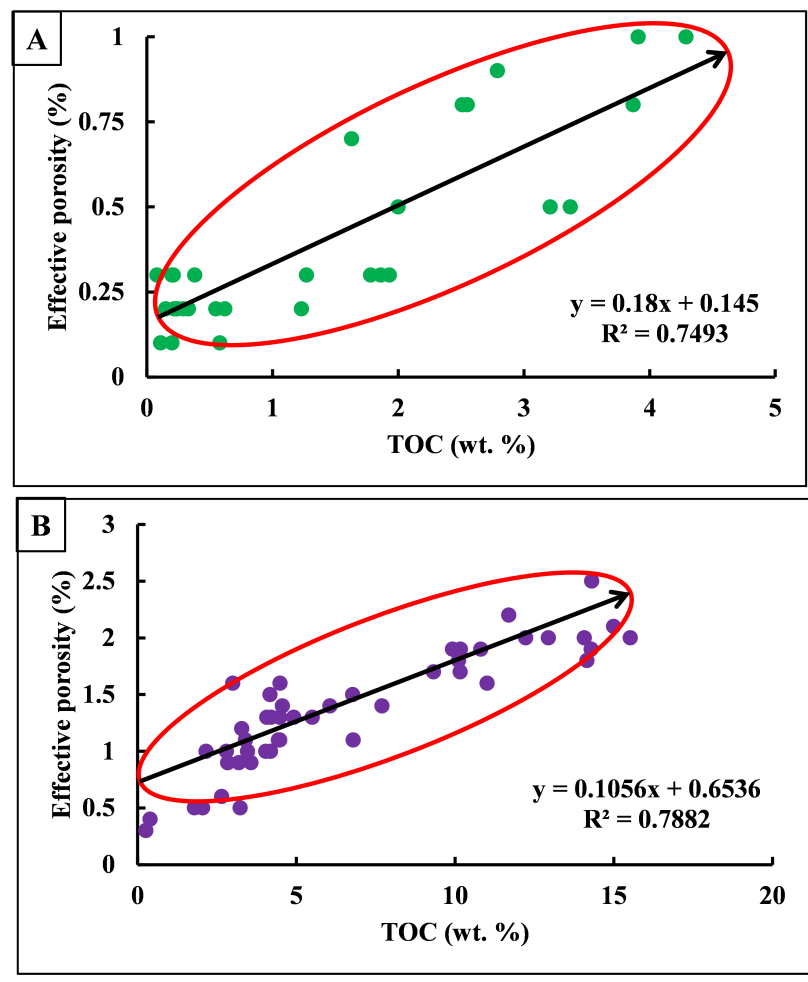

Figure 2: correlation diagram of effective porosity and TOC content in shale. A: Upper Ordovician Xinkailing-Lower Silurian first section of the Lishuwo Formation in Jiangye-1 well; B: Lower Cambrian Wangyinpu Formation in Jiangye-1 well.

technique. From Figure 3B and Figure 3C, it can be seen that the area of organic matter extracted by FIB-SEM overlap with that of the connected pores, indicating that the connected pores are mainly developed in organic matter and shale organic pores, which is the main reservoir space of shale gas.

The above study shows that organic matter is not only the material basis of shale hydrocarbon generation, but also the main reservoir space and seepage channel of shale gas, thus, the content of organic carbon is an important factor for shale gas evaluation. The abundance of organic matter in the original sediments and the degree of thermal evolution affect the TOC content in the shale. Under the condition of a certain degrees of thermal evolution, the organic carbon in the shale is controlled by the abundance of original organic matter. Therefore, the main controlling factors of the abundance of the original sedimentary organic matter is an important problem that is urgently needed to solve. 

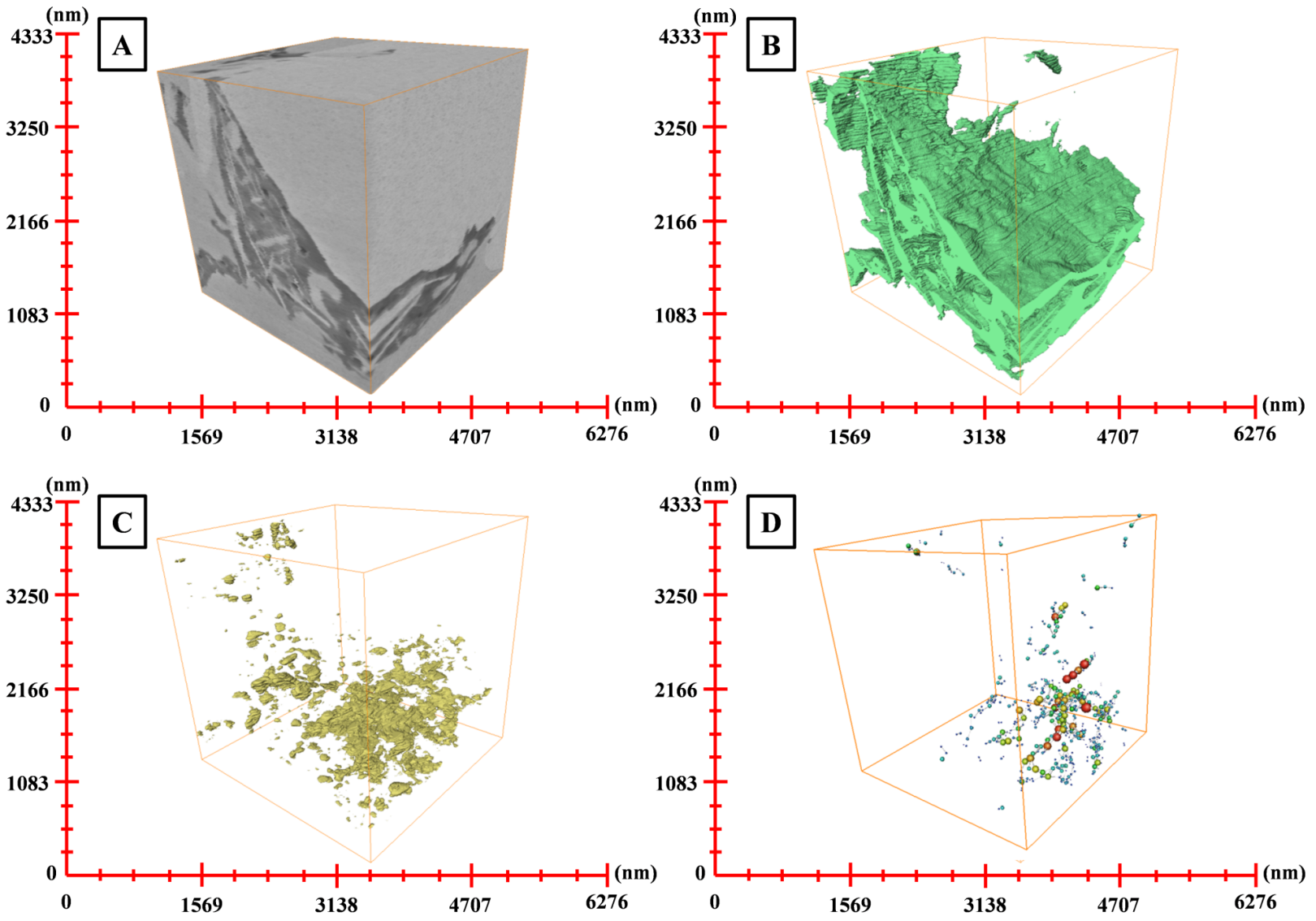

Figure 3: Focused ion beam scanning electron microscope (FIB-SEM) image of Lower Cambrian Wangyinpu Formation in Jiangye-1 well. A: 3D scanning results; B: Organic matter development characteristics; C: Pore development characteristics of organic matter; D: connectivity pore network characteristics. See Fig. 1 for the well location.

\subsection{Calculation of excess silicon and analysis of its origins}

\subsubsection{The Lower Cambrian}

To accurately analyze the mechanism of accumulation of organic matter, the concept and application of excess silicon are introduced in this study. The sources of silicon are divided into two types, normal terrigenous clastic sediments and hydrothermal silicon and biogenic-silicon under special circumstances [32-36]. The excess siliceous mineral content $\left(\mathrm{Si}_{e x}\right)$ refers to the siliceous minerals excluding the normal terrigenous clastic sediments. The excess silicon content can be calculated by the following formula.

$$
S i_{e x}=S i_{s}-\left[(S i / A l)_{b g} \times A l_{s}\right]
$$

In the formula, $\mathrm{Si}_{s}$ is the content of silicon in samples, while $\mathrm{Al}_{s}$ is the content of aluminum in samples, and the value of $(\mathrm{Si} / \mathrm{Al})_{b g}$ is 3.11 , which is the average content for shale [20].
The excess silicon content of the Wangyinpu Formation in the Lower Cambrian of Well Jiangye-1 was calculated using this formula, and the results are shown in Fig. 4. It indicates that excess silicon exists in most layers of the Wangyinpu Formation. Regarding the excess silicon content in the layers where excess silicon exists, half of the layers range from $20 \%-30 \%$, part of the layers from $30 \%-$ $40 \%$, and even some of the layers up to $40 \%-50 \%$.

The Al-Fe-Mn triangulation method is used in the studies of Wedepohl, Adachi et al. and Yamamoto to determine whether siliceous minerals are of hydrothermal or biogenic origin [21-23]. In this paper, the test values of the elements $\mathrm{Al}, \mathrm{Fe}$ and $\mathrm{Mn}$ are collected on a triangular diagram, which are from the intervals in the first member of the Wangyinpu Formation in the Lower Cambrian of Well Jiangye-1 where excess silicon exists. As shown in Fig. 5, the values plot basically in the hydrothermal-origin area, indicating that the excess silicon is of hydrothermal origin. Thus, the figure illustrates that the vertical siliceous source of the shale of the Wangyinpu Formation in the 
Lower Cambrian of Well Jiangye-1, as shown on the right side of Fig. 4, can be reconciled.

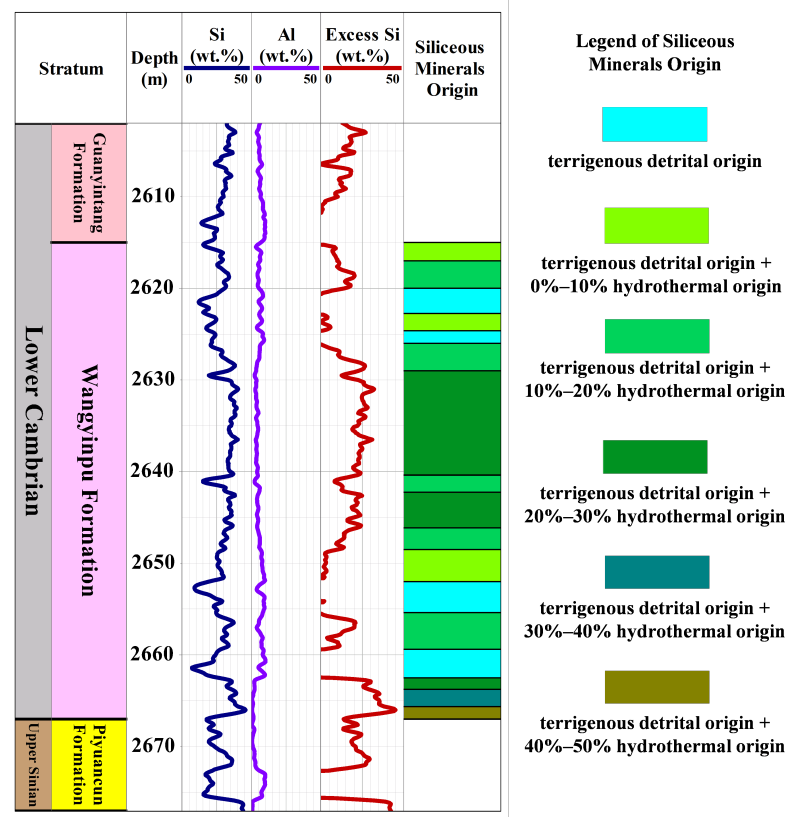

Figure 4: Analysis of excess silicon content in the Wangyinpu Formation in the Lower Cambrian of Well Jiangye-1, Yangtze region. See Fig. 1 for the well location.

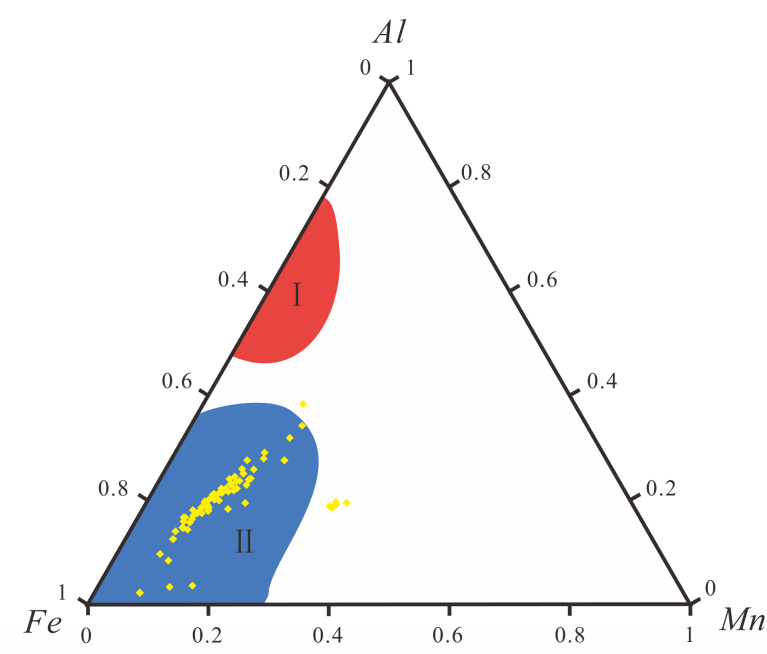

Figure 5: Al-Fe-Mn diagram is used to analyze the source of siliceous minerals in the Lower Cambrian Wangyinpu Formation of Well Jiangye-1, for layers containing excess silicon of hydrothermal origin. See Fig. 1 for the well location. I: bio-origin, II: hydrothermal origin.

\subsubsection{The Upper Ordovician-Lower Silurian}

The Xinkailing Formation in the Upper Ordovician and the first member of the Lishuwo Formation in the Lower Silurian represent another main exploration target in Well Jiangye-1. Excess silicon content is calculated by using the same formula, and the result is shown in Fig. 6. The origin of silicon in the Xinkailing Formation to the first member of the Lishuwo Formation is dichotomous: the silicon of the upper first member of the Lishuwo Formation is mostly of terrigenous origin, and the excess silicon content of a few intervals is from $0 \%-5 \%$;

There is much more excess silicon in the Xinkailing Formation and the first member of Lishuwo Formation, and the excess silicon content of most of the intervals is greater than $0 \%-5 \%$, relatively smaller for the intervals of $5 \%-15 \%$, and only a few record highest i.e. $15 \%-20 \%$, which are relatively lower than the values in the Wangyinpu Formation in the Lower Cambrian. Because the gasbearing properties of the lower part of the Xingkailin Formation and the first member of the Lishuwo Formation is obviously better than that of the upper part of the Xingkailin Formation and the first member of the Lishuwo Formation, the intervals with excess silicon content of over $5 \%$ is defined as favorable intervals for shale gas prospection.

The same method as the study in the Lower Cambrian has been used to determine the origin of silicon. As shown in Fig. 7, the values plot in the field of hydrothermal origin, indicating that the excess silicon is of hydrothermal origin as well. Thus, the figure illustrates that the shale vertical siliceous source of the Xinkailing Formation in the Upper Ordovician and the first member of the Lishuwo Formation in the Lower Silurian of Well Jiangye-1, as shown on the right side of Fig. 6, be reconciled.

\subsection{Effect of hydrothermal activity on enrichment of organic matter}

On one hand, hydrothermal activities form siliceous minerals in shale, and on the other, they affect the redox conditions and biological fertility of water, thereby influencing the abundance of sedimentary organic matter.

\subsubsection{Redox conditions of water body}

The studies of Sun et al. and Zhang et al. found that the reductive acidic hydrothermal waters flowed into the sea and then caused the formation of a hypoxic environment 


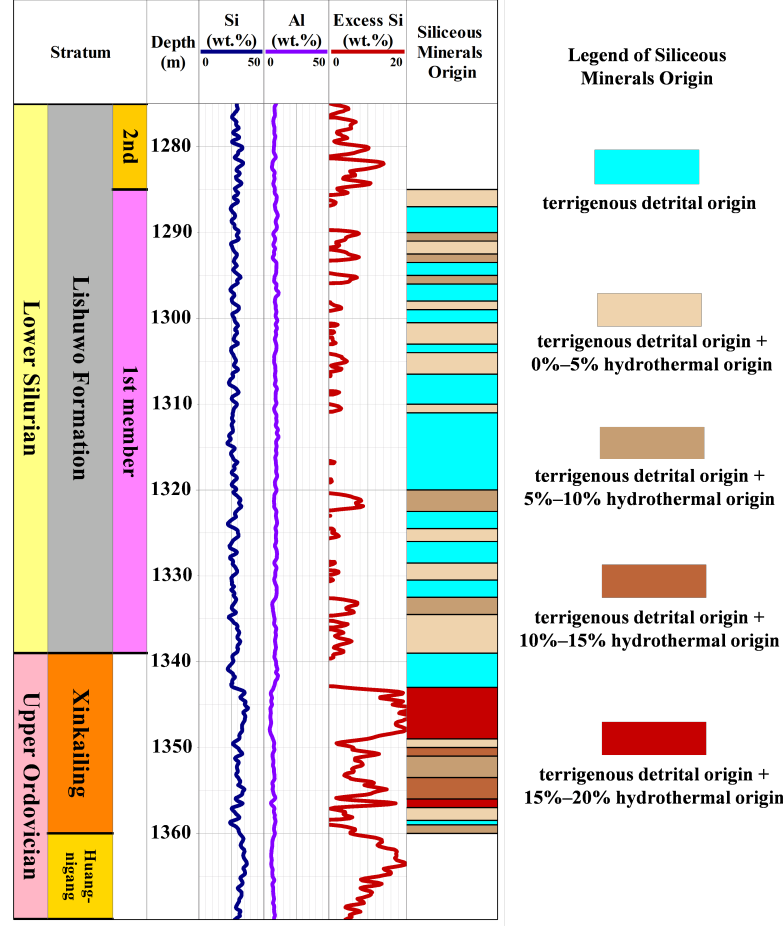

Figure 6: Analysis of excess silicon content in the Xinkailing Formation in the Upper Ordovician and the first member of the Lishuwo Formation in the Lower Silurian of Well Jiangye-1, Yangtze region. See Fig. 1 for the well location.

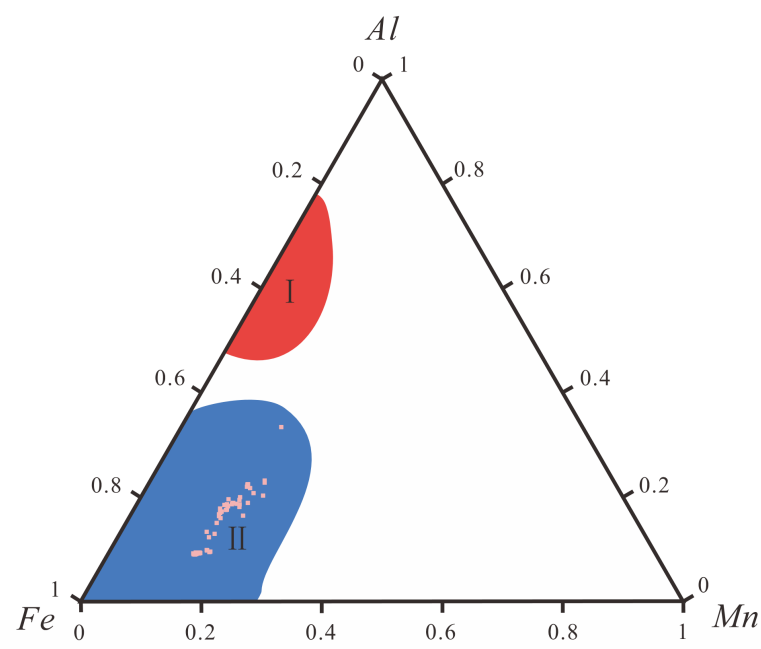

Figure 7: Al-Fe-Mn diagram is used to analyze the source of siliceous minerals in the Xinkailing Formation in the Upper Ordovician and the first member of the Lishuwo Formation in the Lower Silurian of Well Jiangye-1, for layers containing excess silicon of hydrothermal origin. See Fig. 1 for the well location. I: bio-origin, II: hydrothermal origin.

conducive to the preservation of organic matter [37-39]. He et al. conducted research on the black shale of the Lower
Cambrian in the upper Yangtze region and observed that free oxygen in water was consumed due to decomposition of organic matter and biological respiration caused by high biological fertility [40]. Stratification occurred in waters of the Early Cambrian, with a large amount of plankton growth on the surface, while there was hypoxia at the bottom, very conducive for preservation of organic matter.

It is a common method to determine the sedimentary environment using element geochemical indicators. Jones andManning has suggested that the $\mathrm{U} / \mathrm{Th}$ ratio can reflect sedimentary redox conditions through the analysis of all rock samples [41]. In general, U/Th $>1.25$ represents a hypoxic reduction environment, $\mathrm{U} / \mathrm{Th}$ ratios between 0.75 and 1.25 represent an oxygen-poor environment, and U/Th $<0.75$ represents an oxidation environment. Hydrothermal activity of the Early Cambrian in the Xiuwu basin also has certain relevance for water redox conditions. As presented in Fig. 2 and 6, hydrothermal activity was more frequent in the Wangyinpu Formation in the Lower Cambrian of Well Jiangye-1. The excess silicon content of most layers is $20 \%-50 \%$, and the $\mathrm{U} / \mathrm{Th}$ ratio and the redox index is correspondingly higher at $2-16$, reflecting the strong reduction of the water. However, hydrothermal activity was weak in the Upper Ordovician-Lower Silurian, where the excess silicon content of most layers is $10 \%-20 \%$ with low U/Th ratios of $0-1.25$, reflecting oxidation and oxygen-poor environments of the water.

\subsubsection{Biological productivity}

The relationship of hydrothermal activity with the paleoproductivity have been studied previously. Through studying the area of the Halbach et al. studied the hydrothermally active Fiji basin and found that with the increasing distance from the source of hydrothermal activity, the amount and intensity of biological activity in the water increases correspondingly 1-3 times higher compared to the normal oceanic surface [42]. McKibben et al. and Korzhinsky et al. proposed that hydrothermal waters can carry many elements rare to the surface of the crust, and such dissolved microelements include many nutrients necessary for marine life (Si, N, P, Fe, and Zn) [43, 44]. After the death of plankton, their remains slowly descended to the bottom of the sea, like snowing, composing the sources of organic matter enrichment in source rock.

The concentration of the element $\mathrm{Ba}$ is an index widely used to reflect the productivity of ancient marine organisms. On the surface of rotten organic matter, there is a high concentration of $\mathrm{SO}_{4}{ }^{2-}$ ions formed by oxidation of $\mathrm{H}_{2} \mathrm{~S}$ (reoxidized), which precipitates with $\mathrm{Ba}^{2+}$ in seawa- 
ter. Therefore, the content of $\mathrm{BaSO}_{4}$ in high productivity areas is generally high as well. The trace elements in the rock are composed of two parts: the terrestrial input component and the authigenic component. Only the authigenic components can reflect the characteristics of the paleosedimentary environments. Barium derived only from biological action is called excess barium $\left(\mathrm{Ba}_{X S}\right)$, which is generally estimated using the content of $\mathrm{Ba}$ from the terrigenous clastics to reduce the total content of Ba.

$$
B a_{x S}=B a_{S}-A l_{S}(B a / A l)_{P A A S}
$$

In the formula, $\mathrm{Ba}_{s}$ and $\mathrm{Al}_{s}$ are the total content of $\mathrm{Ba}$ and $\mathrm{Al}$, respectively, in the tested samples. PAAS means postArchean Australian shale; whereas $(\mathrm{Ba} / \mathrm{Al})_{P A A S}$ is the ratio of the two elements in the standard shale, which is 0.0077 . The results of the calculation of the excess barium in the Lower Cambrian and the Upper Ordovician-Lower Silurian are shown in Fig. 8 and Fig. 9, respectively.

In oxygen-poor anaerobic environments, the sulfate ion in $\mathrm{BaSO}_{4}$ is reduced by vulcanized bacteria, which dissolve a large amount of $\mathrm{BaSO}_{4}$ and lose a part of the biological Ba [45]. Hydrothermal activity and biological fertility have certain relevance in the Xiuwu basin. As Fig. 6 shows, the Early Cambrian Wangyinpu Formation has relatively more frequent hydrothermal activity, although with strong reduction caused by the large amount of excess barium dissolved, and the remaining content of excess barium is still relatively higher than those of the overlying Guanyintang Formation and the underlying Piyuancun Formation. From Fig. 7, it can be seen that although in the Late Ordovician-Early Silurian, hydrothermal activity is much weaker than that in the Early Cambrian, there is much hydrothermal activity in the Xinkailing Formation and at the bottom of the first member of the Lishuwo Formation, and the excess barium content is higher than that of the upper part of the first member of the Lishuwo Formation.

The extensional state of the Yangtze and Cathaysian plates in the Early Cambrian led to the development of hydrothermal activity, which further caused the excess silicon content of most layers in the Wangyinpu Formation to range from $20 \%-50 \%$, producing TOC content up to $3.5 \%-$ $16 \%$. In the Late Ordovician to Early Silurian, the collision of the Yangtze plate and the Cathaysian plate weakened the hydrothermal activity sharply. The excess silicon content of the Xinkailing Formation and the lower part of the first member of the Lishuwo Formation ranges from 10$20 \%$, producing content of TOC of $1.5 \%-4 \%$. While the excess silicon content of the upper part of the first member of the Lishuwo Formation is $0-5 \%$, the TOC content is lower than $0.5 \%$ in general.

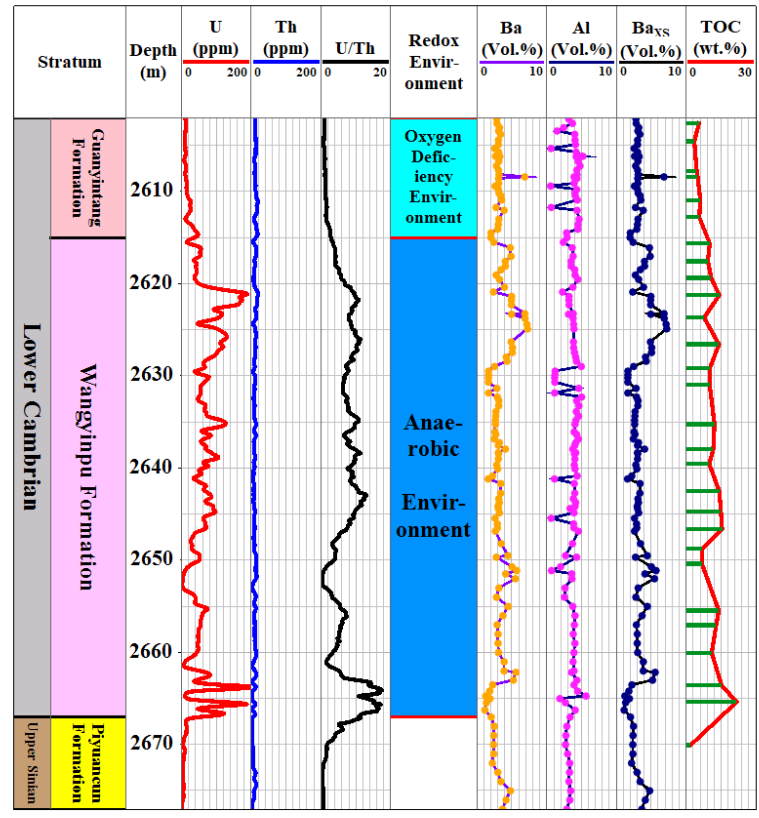

Figure 8: Redox environments, biological fertility (Baxs) and TOC content of Well Jiangye-1 in the Lower Cambrian Wangyinpu Formation, Yangtze region. See Fig. 1 for the well location.

\subsection{Model of organic matter enrichment}

The Xiuwu basin is located in the south margin of the Lower Yangtze region, near the junction of the Yangtze and Cathaysian plates, separated by the ancient Chinese Southern Sea in the Early Cambrian. During the period of deposition of the Wangyinpu Formation, large-scale transgression occurred. Due to the oceanic spreading, tension at the junction of tectonic plates is strong. Thus, fractures develop and deep crustal material upwells, sea water seeps into the fractures carrying out material from the deep crust and heating up to become hydrothermal waters rich in minerals ( $\mathrm{Si}, \mathrm{N}, \mathrm{P}, \mathrm{Fe}, \mathrm{Zn}$ ). In the action of the upward flow, hydrothermal waters flowed into the deepwater shelf area. On the one hand, they reached the sea surface, carrying nutrients conducive to plankton growth and improving biological productivity. On the other hand, they formed reducing environments at the bottom of the sea that were favorable for the preservation of original sedimentary organic matter. This was deposited together with terrigenous clay minerals, siliceous clastics, a small amount of carbonate minerals and biological organic matter from the surface of the water and then formed the shale in the Wangyinpu Formation with high TOC containing much silicon of hydrothermal origin (Fig. 10A).

During the period of the deposition of the Xinkailing Formation to the first member of the Lishuwo Formation, 


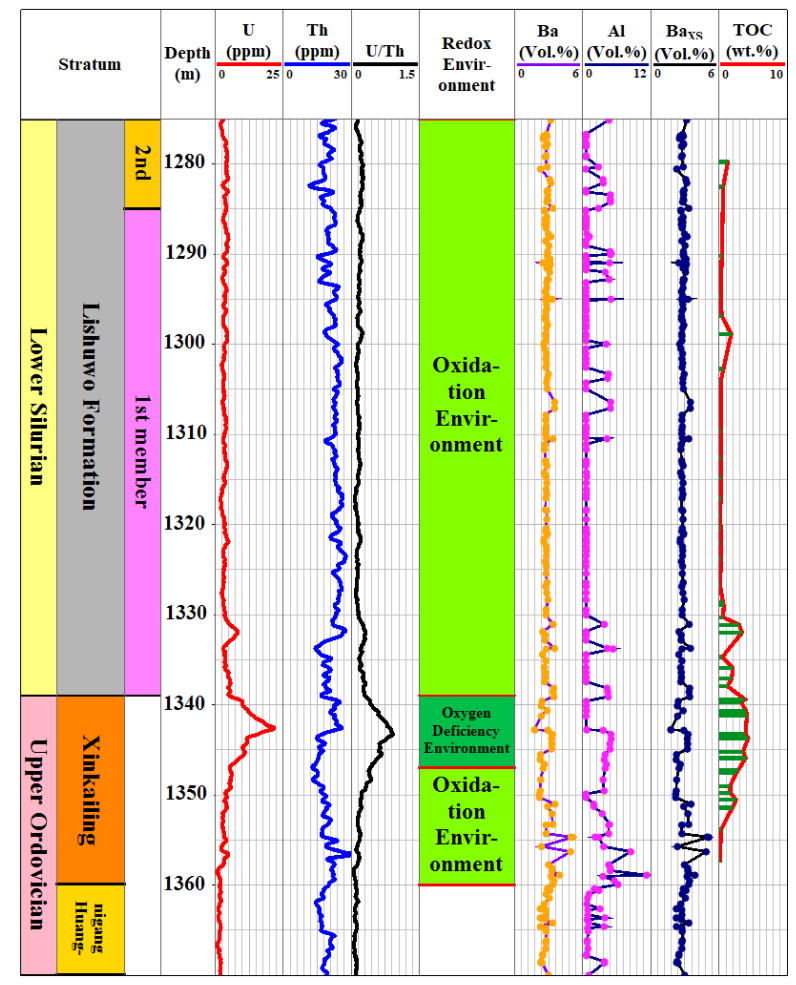

Figure 9: Redox environments, biological fertility (Baxs) and TOC content of Well Jiangye-1 in the Upper Ordovician Xinkailing Formation to the Lower Silurian first member of the Lishuwo Formation, Yangtze region. See Fig. 1 for the well location.

at the plate junction, the Yangtze and Cathaysian plates were colliding and reducing the source of hydrothermal waters and the nutrient supply to the sea surface, resulting in decreasing biological productivity. At the same time, the reduction of water at the bottom of the sea was weakened; and the original sedimentary organic matter was vulnerable to oxidative damage. Because of the shallower water in the Late Ordovician to Early Silurian compared with the Early Cambrian and the smaller distance to the paleouplift, the sources of terrigenous siliceous clastic and clay minerals increased relatively, and the shale of the Xinkailing Formation and the first member of the Lishuwo Formation developed with low amounts of silicon of hydrothermal origin and relatively low TOC (Fig. 10B).

Through the above analysis, it is known that the intensity of hydrothermal activities controls the redox environment at the bottom of the water and the bio-productivity of the surface water, thus affecting the enrichment of the organic matter in the sediments, and further controlling the TOC content of the shale. This conclusion means that the place near the junction of Yangtze plate and Cathaysian plate, where hydrothermal activities were more developed, is favorable area for shale gas exploration in the Lower Yangtze region.

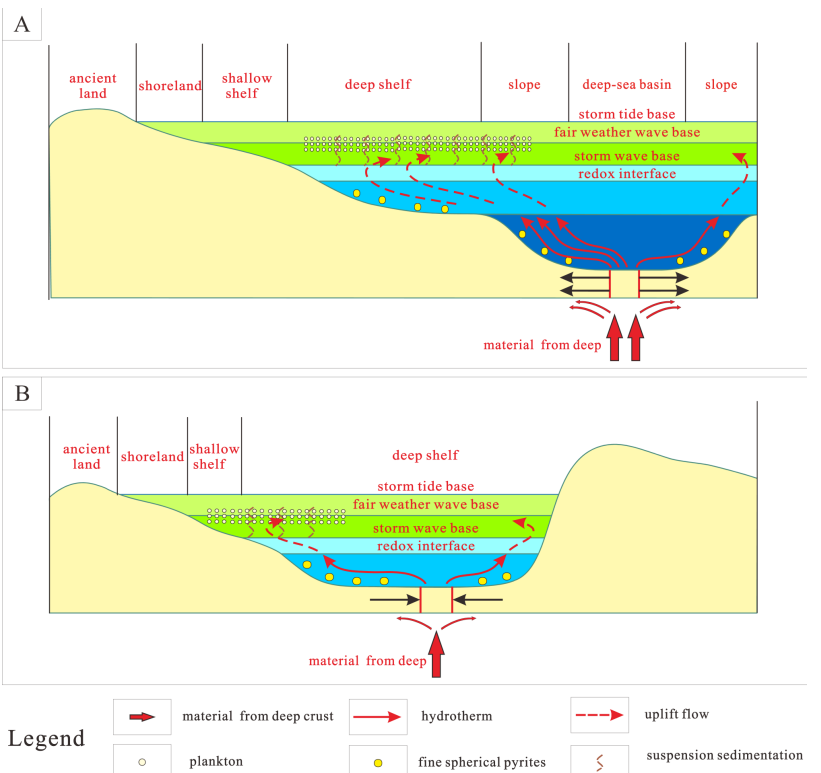

Figure 10: Pattern of organic matter enrichment in the Wangyinpu Formation in the Early Cambrian (A) and the Xinkailing Formation in the Upper Ordovician and the first member of the Lishuwo Formation in the Lower Silurian (B)

\section{Conclusions}

The present study was conducted on the marine shale intervals in the Wangyinpu Formation in the Early Cambrian, the Xinkailing Formation in the Upper Ordovician and the first member of the Lishuwo Formation in the Lower Silurian, in the Lower Yangtze area, southern China, with Well Jiangye-1 drilling the two layers as the research object. Following conclusions were drawn:

(1) In the Lower Cambrian Wangyinpu shale, siliceous minerals of hydrothermal origin exist in most of the intervals, with excess silicon content of $20 \%-50 \%$. While in the Upper Ordovician Xinkailing shale and the lower part of the first member of the Lower Silurian Lishuwo shale, siliceous minerals of hydrothermal origin exist in most of the intervals, with excess silicon content of $10-20 \%$. Further, the excess silicon content of the upper part of the first member of the Lishuwo Formation is only $0-5 \%$. Shales with excess silicon content of more than $5 \%$ is the favorable intervals of shale gas prospection.

(2) The intensity of hydrothermal fluid activities controls the enrichment of organic matter. On the one hand, the 
bio-productivity of the water body is promoted by nutrient elements carried by hydrothermal fluid. On the other hand, the hydrothermal fluid enhances the water reducing, which is beneficial to the preservation of the organic matter.

(3) During the Early Cambrian and Late Ordovician-Early Silurian period, the place near the junction of Yangtze plate and Cathaysian plate, where hydrothermal activities were more developed, is favorable area for shale gas exploration in the Lower Yangtze region.

Acknowledgement: This study was supported by the National Science and Technology Major Project (No. 2017ZX05035-002), the Science Foundation of the Ministry of Land and Resources of China (No. 12120114046701), the National Natural Science Foundation of China (No. 41472112 and No. 41728004) and the open fund from the Sinopec Key Laboratory of Shale Oil/Gas Exploration and Production Technology.

Many thanks to all the anonymous reviewers and the handling editor for their critical comments and constructive suggestions, which we appreciate sincerely.

\section{References}

[1] Curtis, J.B., Fractured shale-gas systems. AAPG Bull., 2002, 86 (11), 1921-1938

[2] Montgomery, S.L., Jarvie, D.M., Bowker, K.A., Pollastro, R.M., Mississippian barnett shale, fort Worth Basin, north-central Texas: gas-shale play with multitrillion cubic foot potential. AAPG Bull., 2005, 89 (2), 155-175

[3] Warlick D., Gas shale and CBM development in North America. Oil \& Gas Financial Journal, 2006, 3(11), 1-5

[4] Zhang, K., Jiang, Z., Xie, X., Gao, Z., Liu, T., Yin, L., Jia, C., Song, Y., Shan, C., Wu, Y., Wang, P., Lateral Percolation and Its Effect on Shale Gas Accumulation on the Basis of Complex Tectonic Background. Geofluids, 2018a, doi: 10.1155/2018/5195469

[5] Dong, D., Wang, Y., Li, X., Zou, C., Guan, Q., Zhang, C., Huang, J., Wang, S., Wang, H., Liu, H., Bai, W., Liang, F., Lin, W., Zhao, Q., Liu, D., Qiu, Z., Breakthrough and prospect of shale gas exploration and development in China. Natural Gas Industry, 2016, 36 (1), 19-32 (in Chinese with English abstract)

[6] Guo, T., Key geological issues and main controls on accumulation and enrichment of Chinese shale gas. Petroleum Exploration and Development, 2016, 43(3), 317-326 (in Chinese with English abstract)

[7] Guo, X., Hu, D., Wei, Z., Li, Y., Wei, X., Discovery and exploration of Fuling shale gas field. China Petroleum Exploration, 2016, 21(3), 24-37 (in Chinese with English abstract)

[8] Wei, X., Zhao, Z., Wang, Q., Liu, Z., Zhou, M., Zhang, H., Comprehensive Evaluation of Geological Conditions of the Shale Gas in Upper Ordovician Wufeng Formation-Lower Silurian Longmaxi Formation in Dingshan Area, Qijiang, Southeastern Sichuan.
Geological Review, 2017, 63(1), 153-164 (in Chinese with English abstract)

[9] Zhang, K., Jiang, Z., Yin, L., Gao, Z., Wang, P., Song, Y., Jia, C., Liu, W., Liu, T., Xie, X., Li, Y., Controlling functions of hydrothermal activity to shale gas content-taking lower Cambrian in Xiuwu Basin as an example. Mar. Pet. Geol. 2017a, 85 (2017), 177193

[10] Zhu, H., Deng, J., Jin, X., Hydraulic Fracture Initiation and Propagation from Wellbore with Oriented Perforation. Rock Mech. Rock Eng., 2015, 48(2), 585-601

[11] Chen, L., Jiang, Z., Liu, K., Wang, P., Ji, W., Gao, F., Hu, T., Zhang, B., Huang, H., Effect of lithofacies on gas storage capacity of marine and continental shales in the Sichuan Basin, China. J. Nat. Gas. Sci. Eng., 2016, 36, 773-785

[12] Zhu, H., Jin, X., Guo, J., Coupled flow, stress and damage modelling of interactions between hydraulic fractures and natural fractures in shale gas reservoirs. Int. J. Oil Gas Coal T., 2016, 13(4), 359-390

[13] Chen, L., Jiang, Z., Liu, K., Tan, J., Gao, F., Wang, P., Pore structure characterization for organic-rich Lower Silurian shale in the Upper Yangtze Platform, South China: A possible mechanism for pore development. J. Nat. Gas. Sci. Eng., 2017, 46, 1-15

[14] Liu, Z., Gao, B., Zhang, Y., Du, W., Feng, D., Nie, H., Types and distribution of the shale sedimentary facies of the Lower Cambrian in Upper Yangtze area, South China. Petroleum Exploration and Development, 2017, 44(1), 21-31 (in Chinese with English abstract)

[15] Li, Y., Qiao, D., Jiang, W., Zhang, C., Gas content of gas-bearing shale and its geological evaluation summary. Geological Bulletin of China, 2011, 30(2/3), 308-317 (in Chinese with English abstract)

[16] Li, Y., Zhao, S., Huang, Y., Zhang, L., Zhang, K, Tang, H., The sedimentary micro-facies study of the Lower Cambrian Qiongzhusi Formation in southern Sichuan Basin. Acta Geologica Sinica, 2013, 87(8), 1136-1148 (in Chinese with English abstract)

[17] Mou, C., Wang, X., Wang, Q., Zhou, K., Liang, W., Ge, X., Chen, $X$. , Relationship between sedimentary facies and shale gas geological conditions of the Lower Silurian Longmaxi Formation in southern Sichuan Basin and its adjacent areas. Journal of Palaeogeography, 2016, 18(3), 457-472 (in Chinese with English abstract)

[18] Liu, Q., Tao, L., Zhu, H., Macroscale Mechanical and Microscale Structure Changes in Chinese Wufeng Shale with Supercritical Carbon Dioxide Fracturing. SPE J., 2017, 23(3), 691-703

[19] Zhang, Y., He, Z., Jiang, S., Gao, B., Liu, Z., Han, B., Wang, H., Marine redox stratification during the early Cambrian (ca. 529-509 $\mathrm{Ma}$ ) and its control on the development of organic-rich shales in Yangtze Platform. Geochem. Geophys. Geosyst., 2017b, 18, 2354-2369

[20] Holdaway, H.K., Clayton, C.J., Preservation of shell microstructure in silicified brachiopods from the upper cretaceous Wilmington sands of Devon. Geol. Mag., 1982, 119, 371-382

[21] Wedepohl, K.H., Environmental influences on the chemical composition of shales and clays. Phys. Chem. Earth, 1971, 8, 307331

[22] Adachi, M., Yamamoto, K., Sugisaki, R., Hydrothermal chert and associated siliceous rocks from the Northern Pacific: their geological significance as indication of ocean ridge activity. Sediment. Geol., 1986, 47 (1), 125-148 
[23] Yamamoto, K., Geochimical characteristics and depositional environments of cherts and associated rocks in the Franciscan and Shimanto terrenes. Sediment. Geol., 1987, 52, 65-108

[24] Zhu, M., Zhang, J., Yang, A., Li, G., Steiner, M., Erdtmann, B.D., Sinian-Cambrian stratigraphic framework for shallow-to deepwater environments of the Yangtze Platform: An integrated approach. Prog. Nat. Sci., 2003, 13(12), 951-960

[25] Zhu, M., Babcock, L.E., Peng, S., Advances in Cambrian stratigraphy and paleontology: Integrating correlation techniques, paleobiology, taphonomy and paleoenvironmental reconstruction. Palaeoworld, 2006, 15(3/4), 217-222

[26] Zhang, K., Li, Z., Jiang, S., Jiang, Z., Wen, M., Jia, C., Song, Y., Liu, W., Huang, Y., Xie, X., Liu, T., Wang, P., Shan, C., Wu, L., Comparative Analysis of the Siliceous Source and Organic Matter Enrichment Mechanism of the Upper Ordovician-Lower Silurian Shale in the Upper-Lower Yangtze Area. Minerals, 2018b, 8, doi:10.3390/min8070283

[27] Wang, Y., Dong, D., Li, X., Huang, J., Wang, S., Wu, W., Stratigraphic sequence and sedimentary characteristics of Lower Silurian Longmaxi Formation in the Sichuan Basin and its peripheral areas. Natural Gas Industry, 2015, 35(3), 12-21 (in Chinese with English abstract)

[28] Zou, C., Dong, D., Wang, Y., Li, X., Huang, J., Wang, S., Guan, Q., Zhang, C., Wang, H., Liu, H., Bai, W., Liang, F., Lin, W., Zhao, Q., Liu, D., Yang, Z., Liang, P., Sun, S., Qiu, Z., Shale gas in China: Characteristics, challenges and prospects (I). Petrol. Explor. Dev., 2015, 42(6), 689-701 (in Chinese with English abstract)

[29] Li, Z., Zhang, L., Powell, C. M., South China in Rodinia: Part of the missing link between Australia-east Antarctica and Laurentia? .Geology, 1995, 23(5), 407-410

[30] Li, Z., Li, X., Zhou, H., Kinny, P.D., Grenvillian continental collision in South China: New SHRIMP U-Pb zircon results and implications for the configuration of Rodinia. Geology, 2002, 30(2), 163-166

[31] Wang, J., Li, Z., History of Neoproterozoic rift basins in South China: Implications for Rodinia break-up. PreCambrian Res., 2003, 122 (1/4), 141-158

[32] Bostrom, K., Kraemer, T., Gratner, S., Provenance and accumulation rates of opaline silica, $\mathrm{Al}, \mathrm{Ti}, \mathrm{Fe}, \mathrm{Mn}, \mathrm{Cu}, \mathrm{Ni}$, and $\mathrm{Co}$ in Pacific pelagic sediments. Chem. Geol., 1973, 11(2), 123-148

[33] Murray, R.W., Buchholtz, T. B. M. R., Gerlach, D.C., Rare earth, major, and trace elements in chert form the Franciscan complex and monterey group, California: assessing REE sources to fine-grained marine sediments. Geochim. Cosmochim. Ac., 1991, 55(7), 1875-1895

[34] Liu, J., Zheng, M., Geochemistry of hydrothermal sedimentary silicalite. Acta Geological Sichuan, 1993, 13(2), 110-118 (in Chinese with English abstract)
[35] Yang, J., Wang, D., Mao, J., Zhang, Z., Zhang, Z., Wang, Z., The petrochemical research method for silicalite and its application to the "Jingtieshan Type" iron deposits. Acta Petrologica et Mineralogical, 1999, 18(2), 108-118 (in Chinese with English abstract)

[36] Liu, J., Li, Y., Zhang, Y., Liu, S., Cai, Y., Evidences of biogenic silica of Wufeng-Longmaxi Formation shale in Jiaoshiba area and its geological significance. Journal of China University of Petroleum (Edition of Natural Science), 2017, 41(1), 34-41 (in Chinese with English abstract)

[37] Sun, X., Chen, J., Liu, W., Zhang, S., Wang, D., Hydrothermal venting on the seafloor and formation of organicerich sediments: evidence from the Neoproterozoic Xiamaling Formation, North China. Geol. Rev., 2003, 49(6), 588-595 (in Chinese with English abstract)

[38] Sun, X., Chen, J., Zheng, J., Liu, W., Geochemical characteristics of organic matter-rich sedimentary strata in lower Cambrian, Tarim Basin and its origins. Acta Sedimentol. Sin., 2004, 22 (3), 548-552 (in Chinese with English abstract)

[39] Zhang, W., Yang, H., Xie, L., Yang, Y., Lake-bottom hydrothermal activities and their influences on the high-quality source rock development: a case from Chang 7 source rocks in Ordos Basin, China. Petroleum Exploration and Development, 2010, 37 (4), 424-429 (in Chinese with English abstract)

[40] He, J., Duan, Y., Zhang, X., Wu, B., Xu, L., Hydrocarbon generation conditions of the shale in niutitang formation of lower Cambrian, Southern Chongqing and Northern Guizhou, China. Marine Geology Frontiers, 2011, 27(7), 34-40 (in Chinese with English abstract)

[41] Jones, B., Manning, D.A.C., Comparison of geochemical indices used for the interpretation of palaeoredox conditions in ancient mudstones. Chem. Geol., 1994, 111(1/4), 111-129

[42] Halbach, M., Koschinsky, A., Halbach, P., Report on the discovery of gallionella ferruginea from an active hydrothermal field in the deep sea. Int. Ridge-Crest Res., 2001, 10(1), 18-20

[43] McKibben, M.A., Williams, A.E., Hall, G.E.M., Solubility and transport of plantinum-group elements and $\mathrm{Au}$ in saline hydrothermal fluids; constraints from geothermal brine data. Econ. Geol., 1990, 85(8), 1926-1934

[44] Korzhinsky, M.A., Tkachenko, S.,I., Shmlovich, K.,I., Discovery of a purerhenium mineral at Kudriavy volcano. Nature, 1994, 369, 51-52

[45] Wei, H., Productivity and redox proxies of palaeo-oceans: An overview of elementary geochemistry. Sedimentary Geology and Tethyan Geology, 2012, 32 (2), 76-88 (in Chinese with English abstract) 